\title{
Architecture development of temples and chapels of Christian theological-humanitarian educational institutions in Ukraine
}

\begin{abstract}
The article highlights the sacred component of architecture of theological-humanitarian Christian educational institutions. It researches the architectural and space-planning decisions of temples and chapels of theological-humanitarian educational institutions.

The objective of the research is to determine the major principles of architecture development common for the sacred core of theological-humanitarian educational institutions.

The research has been conducted by means of analyzing the historical experience of designing and constructing temples and chapels of theological educational institutions in Ukraine, carrying out field observations, systematizing the results of previous scientific researches, as well as analyzing the design decisions and the implemented projects. The methods of typological analysis, experimental design, and questionnaire-based survey have been applied in the course of the research.

The results of the conducted research helped to outline the major principles of architecture development common for the sacred core of theological-humanitarian educational institutions, determine the major factors influencing the architecture of temples and chapels of similar institutions, and offer the suggestions for designing temples and chapels of theological-humanitarian educational institutions in Ukraine.
\end{abstract}

Key words: architecture, sacredness, temple, chapel, education, science, theological seminary, theological-humanitarian university

\section{Introduction}

The development of the world civilization is based on the spiritual and material background, the development of theological and secular education, the harmony of faith and real opportunities, the general human values, and the specificity of the world view that is adherent to different social and religious communities. As a part of the Christian world, Ukraine is gradually returning to the spiritual origins of education, especially in the realm of humanitarian education [5].

The architectural and space-planning organization of the newly established theological-humanitarian educational institutions in Ukraine is based on the traditional types of theological educational institutions, in which temples are endowed with special spiritual and functional meaning. However, the dynamic development of architecture of theological and educational centers requires new approaches and knowledge of architectural and spaceplanning organization of temples and chapels located on the territories of educational campuses. It calls for the new humanitarian and high-tech architecture, which would be elaborated as based on the principles of faith and high level of general spirituality.

The development of architectural typology of temples belonging to theological-humanitarian educational institutions and their architectural and functional orga- nization on the Ukrainian terrains are covered not sufficiently and, thus, require specialized research. The contemporary tendencies of designing and constructing temples of theological-humanitarian educational institutions in Ukraine are characterized by combining the traditional sacred architecture and the modern architecture of secular educational institutions. However, such approach is a very simplified model of architectural and spaceplanning organization of a temple in a theologicalhumanitarian educational institution and does not fully take into account the specificity of functional structure that includes both the sacred component and the academic purpose of a building. The problem of the complex approach to designing temples and chapels of theological-humanitarian educational institutions in Ukraine has not been reflected in the official regulatory documents and, thus, scientists are required to elaborate the theoretical basis of the methodology of designing temples and chapels belonging to this type. The analysis of modern architecture tendencies applicable to temples of theological-humanitarian institutions in Ukraine enabled the possibility of conducting the comprehensive research on the architectural typology of such temples, determining the major factors 
that have the most significant impact on the architecture development, establishing the basic architectura principles, and outlining the methodology of designing modern temples (chapels) of theological-humanitarian educational institutions in Ukraine.

\section{The aim of the publication}

The aim of the publication is to research and analyze the architectural specificity of temples and chapels of theological and theological-humanitarian institutions in Ukraine, determine the major principles of their architecture development, outline the key factors that have the most significant impact on the sacred core architecture and make suggestions concerning the design of churchtheological-humanitarian educational institutions.

3. The analysis of recent researches and publications The architecture development of temples and chapels institutions has been rogeral ha brainian scientists, architects, historians, and theologians. Among them, is necessary to emphasize the researches on theological educational institution architecture conducted by professor V. I. Proskuryakov [7][14], associate professor R. Z. Stotsko $[7,8,9]$, associate professor O. I. Zhovkva [10]. The scientific works by the architects and scientists L. O. Shuldan [11], M.B. Yatsiv [12], O. V. Shcherbakov [13], and O. Yu. Dmytrash cover the topic of architecture of secular educational institutions [14]. Additionally, in some of the studies, R. Halyshysh describes the Ukrainian church architecture and the monumental and decorative art of the foreign communities [15]; Yu. 1. Kryvoruchko investigates the theological foundations of sacred architecture [3], V. I. Turchyn studies the bearers of traditions in the sacred architecture in Ukraine [2]; Blazejowskyi D. works on the problems of Ukrainian Catholic Clergy in Diaspora [16]; Ewa Weclawowicz Gyurkovich works on the problems of Phenomenon of polish religious architecture of the end of the twentieth century [17]; Beata Malinowska Petelenz studies the Temples of Europe and their cultural contexts [18] Having analyzed the knowledge about temple and cha-

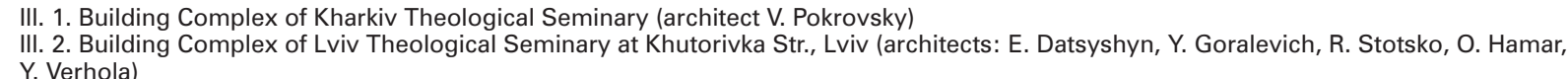
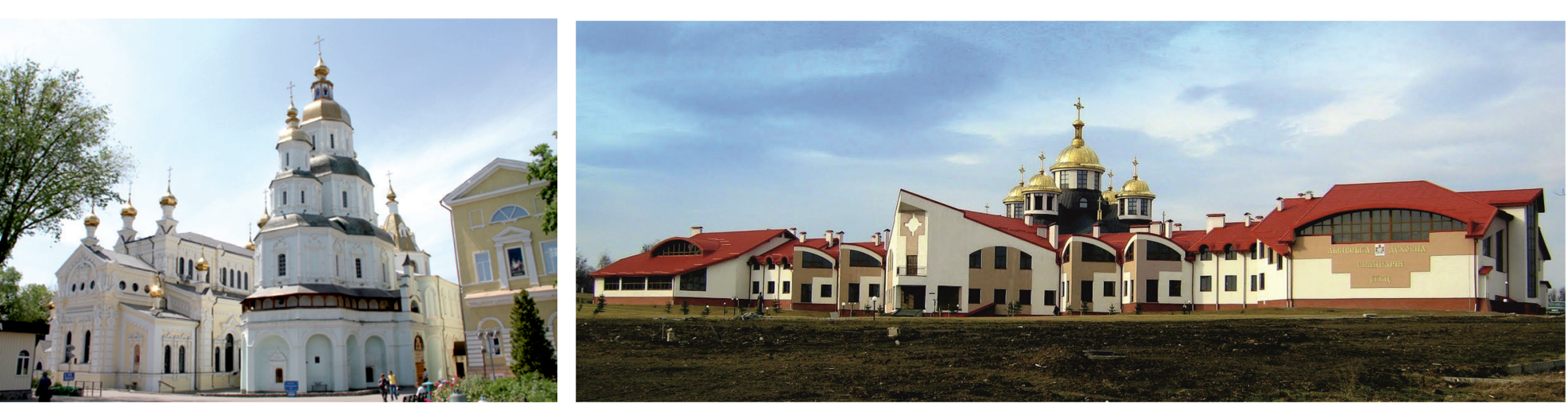

a) main facade has the minimum possible width, i.e. buildings of the theological-humanitarian educationa complex are arranged deep in the campus heartland and it can be defined as campus of the "deep" type (Ukrainian Catholic University at Stryiska Street, Lviv Kharkiv Theological Seminary, III. 1)

b) main facade has the significant width, i.e. building of the theological-humanitarian educational complex are arranged widthwise and it can be defined as campus of the "frontal" type. Buildings that constitute the main facade of the complex are visually balanced with respect to the center constituted by an axes of symmetry of the main building, which is the temple (LViv Theological Seminary of UlKaich is Greek Catholic

c) main facade of the theological-humanitarian edubuilding complex can be defined as campus of the "free" type. Only the central entrance to the temple the administrative building, which are visully empha sized to the largest Theological Seminary) [8]

From the spiritual and ideological perspective, as well as in the context of architectural and space-planning or ganization, a temple is the main and visually dominant building in the structure of the theological-humanitarian educational institution. This factor is defining for the urban planning decisions and for the formation of the general construction plan of theological-humanitaria educational institutions. A temple of theological-humanitarian educational institution is not freely accessible for parishioners. In many universities, seminaries, and academies in Ukraine, temples and chapels are constructed only for the internal usage. This limitation is also related to educational monastery complexes, where a temple or a chapel is always closed for parish ioners. The accessibility of a temple located on the terains of theological-humanitarian educational institution for citizens of the city is determined by the administration of the educational institution and the local diocesa authorities [9]. As based on this circumstance, two type of temple location within the boundaries of a campus an be outlined:

Theological-humanitarian educational institution with the free access to a temple - educational institution is constructed on one of the main streets or squares of visul dominant feare of the theologicathumitarian education complex and the street (square) in general. The main entrance to the temple is directed at the street or square and is not separated from the secular public space by any fence. There can be a few variants of tem ple location on the territory of the campus belonging to this type: a) the temple is located on the axis of symmetry of the complex without any attachment to building (the temple clearly identifies the nature of the institution there is the possibility of conducting ceremonial walks around it and it is easily accessible for parishioners); b asymmetrical location of the temple without any attachment to buildings (the temple is easily accessible for parishioners, there is the possibility of conducting cer- emonial walks around it, and the campus buildings cation of the temple. The temple is integrated into educational and administrative buildings (free planning of the building complex, comfortable transition to the temple through covered walkways).

2. Theological-humanitarian educational institution with an internal closed temple - educational institution may be constructed on the main or peripheral street or square of the city, residential district or quarter. A temple is the visual dominant feature of the educational building complex. Its visual percepis is located in the center sthe complex and its main ple is is not relad from the stret (sy the bulding of

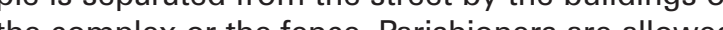

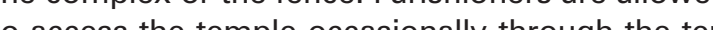
ritory or the buildings of the complex. Closed location of the temple also has a few variants: a) the temple is located in the center of the complex without attachment to buildings (ideologically and functionally, temple is the main building in the complex, there is the possibility of conducting ceremonia walks around it, there is a good visual connection between the temple and educational, administrative, and residential buildings of the complex): $b$ the temple is located in the internal space of the campus and integrated into one of the buildings (free planning of the campus space, transition to the temple directly from the educational buildings) c) the temple is integrated into the building and its altar part oversees the secular public space of the street or square (the temple visually identifies the sacred component of the educational complex, the emple is easily accessible via covered walkways and it does not occupy a separate area on the campus territory) [9]

The architecture of temples and chapels of theological-humanitarian educational institutions in Ukraine is developing in accordance with certain principles. Definition of these principles is the result of the comprehensive architectural studies of temples and chapels of theological-humanitarian educational institutions established by the largest religious groups and denominations in differspace-plinning organization of the sacred cor of ent based on the following principles:

1. Principle of sacredness - architecture of a temple or a sacel indicates the sacred nature a building (planning, composition of elements, shape of domes, sacred symbols, interior paintings, and facade decorations).

2. Principle of adherence to a certain denomination and ecumenical nature - a temple or a chape belongs to a certain religious group or denomination, which is reflected in its planning, architectural stylistics, and decoration of facades. Additionally, architecture of a temple or a chape 
